\title{
Hot Corrosion Behavior of Superalloy in Different Corrosive Environments
}

\author{
Subhash Kamal1*, Korada Viswanath Sharma1, A. M. Abdul-Rani1,2 \\ ${ }^{1}$ Department of Mechanical Engineering, Universiti Teknologi PETRONAS, Tronoh, \\ Malaysia \\ ${ }^{2}$ Centre for Intelligent Signal \& Imaging Research, Universiti Teknologi PETRONAS, Tronoh, Malaysia \\ Email: subhashkamal@gmail.com
}

Received 29 August 2014; revised 8 October 2014; accepted 19 October 2014

Academic Editor: Njiomou Djangang Chantale, University of Yaoundé I, Cameroon

Copyright (C) 2015 by authors and Scientific Research Publishing Inc.

This work is licensed under the Creative Commons Attribution International License (CC BY).

http://creativecommons.org/licenses/by/4.0/

(c) (i) Open Access

\begin{abstract}
Hot corrosion is a serious problem in aircraft, marine, industrial and land-base gas turbines. To obviate these problems, superalloy superfer $800 \mathrm{H}$ (Midhani grade) is one of the prominent materials for the high temperature applications. The present work investigates hot corrosion behaviour of superfer $800 \mathrm{H}$ exposed to two different molten salt environments $\mathrm{Na}_{2} \mathrm{SO}_{4}+60 \% \mathrm{~V}_{2} \mathrm{O}_{5}$ and $\mathrm{Na}_{2} \mathrm{SO}_{4}+5 \% \mathrm{~V}_{2} \mathrm{O}_{5}+5 \% \mathrm{NaCl}$ respectively, at $900^{\circ} \mathrm{C}$ under cyclic conditions. The weight change measurements made on during the experiments are used to determine the kinetics of hot corrosion. It is observed that the formation of scale rich in $\mathrm{Cr}_{2} \mathrm{O}_{3}, \mathrm{NiO}$ and spinel $\mathrm{NiCr}_{2} \mathrm{O}_{4}$ has contributed for the better hot corrosion resistance of superfer $800 \mathrm{H}$. Inspection for 10, 20, 35 and 50 cycles reveals that after 10 cycles Crack has been initiated in the scale and it is clearly visible in the presence of $\mathrm{NaCl}$ salt. On subsequent cycles, crack propagates perpendicular to surface and as it encounters inclusions.
\end{abstract}

\section{Keywords}

Hot Corrosion, Superalloy, Superfer $800 \mathrm{H}$, Cyclic Conditions, Spinel $\mathrm{NiCr}_{2} \mathrm{O}_{4}$

\section{Introduction}

Degradation by high-temperature oxidation, hot corrosion and erosion are the main failure modes of components in the hot sections of gas turbines, boilers, industrial waste incinerators, etc. Superfer $800 \mathrm{H}$ have been developed

*Corresponding author.

How to cite this paper: Kamal, S., Sharma, K.V. and Abdul-Rani, A.M. (2015) Hot Corrosion Behavior of Superalloy in Different Corrosive Environments. Journal of Minerals and Materials Characterization and Engineering, 3, 26-36. 
for high temperature applications, superfer finds application in the gas turbine industry, constituting over $50 \%$ of the gas turbine weight due to their good mechanical properties at elevated temperatures [1]-[4]. Superfer exhibits superior mechanical strength, surface stability, creep and fatigue resistance at high temperature [5]. The turbine engines are exposed to extremely high temperature and harsh environment and therefore tend to suffer from significant material degradation during service [6] [7]. Low-grade fuel oils and fossil fuels used in energy generation systems contains complex mixtures of molten sodium sulfate $\left(\mathrm{Na}_{2} \mathrm{SO}_{4}\right)$ and vanadium pentoxide $\left(\mathrm{V}_{2} \mathrm{O}_{5}\right)$ [8] [9]. The $\mathrm{Na}_{2} \mathrm{SO}_{4}$ can be ingested in the turbine intake air or it can be produced by a reaction between sodium chloride $(\mathrm{NaCl})$ ingested with the intake air and sulfur impurities in the fuel [10]. Vanadium is present in the fuel in the form of vanadium porphyrin, which transforms during combustion into $\mathrm{V}_{2} \mathrm{O}_{5} \cdot \mathrm{V}_{2} \mathrm{O}_{5}$ and $\mathrm{Na}_{2} \mathrm{SO}_{4}$ form low melting point inorganic compounds, which undergoes eutectic reaction below $600^{\circ} \mathrm{C}$. $\mathrm{NaCl}$ is present in marine environment, and together with $\mathrm{Na}_{2} \mathrm{SO}_{4}$ it lowers the eutectic melting point to $620^{\circ} \mathrm{C}$. When the temperature exceed melting point of the deposits [11], these compounds starts slowly depositing on the turbine blades, consequently corrosion rate rapidly increases due to faster transport phenomena in liquid phase which cause catastrophic corrosion phenomena [12]. Hence, for effective and efficient functioning of gas turbine components, it is highly essential to develop superalloy with high-temperature strength as well as good hot corrosion resistance [13]. However, there is still a lack of basic understanding of how these superalloys behave in severe $\left(\mathrm{Na}_{2} \mathrm{SO}_{4}+\right.$ $60 \% \mathrm{~V}_{2} \mathrm{O}_{5}$ ) operating environment. Therefore, the hot corrosion behaviour of superfer $800 \mathrm{H}$ has been investigated at $900^{\circ} \mathrm{C}$ in two most corrosive environments $\left(\mathrm{Na}_{2} \mathrm{SO}_{4}+60 \% \mathrm{~V}_{2} \mathrm{O}_{5}\right.$ and $\left.\mathrm{Na}_{2} \mathrm{SO}_{4}+5 \% \mathrm{~V}_{2} \mathrm{O}_{5}+5 \% \mathrm{NaCl}\right)$ in the present work. The kinetics of corrosion of superalloy substrates was determined from the weight change of the samples calculated during the experiments. Inspections for 10, 20, 35 and 50 reveal the mechanism of hot corrosion via crack propagation. It was found that after 10 cycles Crack has been initiated in the scale and it is clearly visible in the presence of $\mathrm{NaCl}$ salt. On subsequent cycles, crack propagates perpendicular to surface and as it encounters inclusions, intermetallics it starts propagating parallel to surface. Through cracks, molten salts attack the substrate and cause hot corrosion. But extent of corrosion is less as the thickness of scale formed after 50 cycles is not more than $50 \mu \mathrm{m}$ even in most severe environment $\left(\mathrm{Na}_{2} \mathrm{SO}_{4}+60 \% \mathrm{~V}_{2} \mathrm{O}_{5}\right)$. XRD, SEM and FESEM/EDAX, and X-ray mapping were used to characterize the corrosion products in order to render an insight in to the corrosion mechanisms.

\section{Experimental Procedure}

\subsection{Substrate Material}

The Fe-based substrate material selected for this study, namely superfer $800 \mathrm{H}$, were provided by Mishra Dhatu Nigam Limited, Hyderabad (India) in the rolled sheet form. The nominal chemical composition of the substrate materials is reported in Table 1.

\subsection{Substrate Preparation}

The specimens, with dimensions of approximately $20 \times 15 \times 5 \mathrm{~mm}^{3}$, were cut from the alloy sheets of superfer $800 \mathrm{H}$. The specimens were polished using emery papers of 220, 400, 600 grit sizes and subsequently on 1/0, 2/0, $3 / 0$ and $4 / 0$ grades. Final polishing was carried out on a cloth polishing wheel machine with $1 \mu \mathrm{m}$ alumina powder suspension. Subsequently the specimens were properly cleaned with acetone and dried in hot air $\left(250^{\circ} \mathrm{C}\right)$ for 3 - 4 hours.

\subsection{Molten Salt Corrosion Test}

Cyclic studies were performed for the substrate in two different molten salt environments $\left(\mathrm{Na}_{2} \mathrm{SO}_{4}+60 \% \mathrm{~V}_{2} \mathrm{O}_{5}\right.$ and $\mathrm{Na}_{2} \mathrm{SO}_{4}+5 \% \mathrm{~V}_{2} \mathrm{O}_{5}+5 \% \mathrm{NaCl}$ ) for 50 cycles. Each cycle consisted of $1 \mathrm{hr}$ of heating at $900^{\circ} \mathrm{C}$ in a silicon

Table 1. Chemical composition of the substrate material superfer $800 \mathrm{H}$.

\begin{tabular}{|c|c|c|c|c|c|c|c|c|c|c|c|}
\hline \multirow{2}{*}{$\begin{array}{l}\text { Alloy Midhani Grade } \\
\text { (Similar Grade) }\end{array}$} & \multicolumn{11}{|c|}{ Chemical Composition (wt\%) } \\
\hline & $\mathbf{F e}$ & $\mathbf{N i}$ & $\mathrm{Cr}$ & $\mathbf{T i}$ & Al & Mo & Mn & Si & $\mathbf{C u}$ & Ta & C \\
\hline Superfer $800 \mathrm{H}$ (Incoloy $800 \mathrm{H}$ ) & 43.8 & 32.0 & 21.0 & 0.3 & 0.3 & & 1.5 & 1.0 & & & 1.0 \\
\hline
\end{tabular}


carbide tube furnace followed by 20 minutes of cooling at room temperature $\left(25^{\circ} \mathrm{C}\right)$. The purpose of imposing cyclic conditions was to create an accelerated environment as observed in real cases for hot corrosion testing. The specimens were mirror polished down to $1 \mu \mathrm{m}$ alumina on a cloth-polishing wheel before the corrosion run. A coating of uniform thickness with $3-5 \mathrm{mg} / \mathrm{cm}^{2}$ of salt was applied with a camel hair brush on the preheated sample $\left(250^{\circ} \mathrm{C}\right)$. The weight change measurements were taken at the end of each cycle using an electronic balance machine (Model 06120, Contech) with a sensitivity of $1 \mathrm{mg}$. The spalled scale was also included at the time of measurement of the weight change to determine the total rate of corrosion. The kinetics of corrosion was analyzed from the results of weight change measurements. The samples after hot corrosion were analyzed by XRD for the phase identification and FE-SEM/EDAX for surface morphological and compositional analysis and $\mathrm{X}$-ray mapping for cross sectional compositional analysis.

\section{Results}

\subsection{Visual Observations}

The superalloys during hot corrosion in the molten salt environment at $900^{\circ} \mathrm{C}$ have shown spalling/sputtering right from the initial few cycles which intensified with the progress of study with lot of corrosion products formed in the boat. The surface became rougher with progressive exposure of time with a uniform pitting observed throughout the surface of the samples. A greenish scale appeared on the surface of superfer $800 \mathrm{H}$; during initial cycles the colour was dark grey which turned greenish with grey patches. The oxide scale has two regions, with dark and light grey scales, dark grey scale has brownish tinges distributed randomly.

\subsection{Cyclic Hot Corrosion Test}

Figure 1 and Figure 2 show the weight gain/unit area for molten salt $\left(\mathrm{Na}_{2} \mathrm{SO}_{4}+60 \% \mathrm{~V}_{2} \mathrm{O}_{5}\right.$ and $\mathrm{Na}_{2} \mathrm{SO}_{4}+5 \%$ $\mathrm{V}_{2} \mathrm{O}_{5}+5 \% \mathrm{NaCl}$ ) environment, respectively, for the superalloys subjected to $900^{\circ} \mathrm{C}$ for 50 cycles. The parabolic rate constants calculated for the superfer $800 \mathrm{H}$ shows that the corrosion rate is higher in $\mathrm{Na}_{2} \mathrm{SO}_{4}+60 \% \mathrm{~V}_{2} \mathrm{O}_{5}$ environment. The weight gain square $\left(\mathrm{mg}^{2} / \mathrm{cm}^{4}\right.$ ) versus time (number of cycles) plots are drawn to establish the rate law for the hot corrosion. It is observed from the graph that superfer $800 \mathrm{H}$ follows nearly parabolic rate law in both the environment. The parabolic rate constant $K_{p}$ was calculated by a linear least-square algorithm to a function in the form of $(W / A)^{2}=K_{p} t$, where $W / A$ is the weight gain per unit surface area $\left(\mathrm{mg} / \mathrm{cm}^{2}\right)$ and " $t$ " indicates the number of cycles represents the time of exposure. The parabolic rate constants for both the environments $\left(\mathrm{Na}_{2} \mathrm{SO}_{4}+60 \% \mathrm{~V}_{2} \mathrm{O}_{5}\right.$ and $\left.\mathrm{Na}_{2} \mathrm{SO}_{4}+5 \% \mathrm{~V}_{2} \mathrm{O}_{5}+5 \% \mathrm{NaCl}\right)$ were calculated for 10, 20, 35 and 50 cycles and are reported in Table 2.

\subsection{X-Ray Diffraction Analysis (XRD) of Scale}

The XRD patterns for the superfer $800 \mathrm{H}$ subjected to molten salt $\left(\mathrm{Na}_{2} \mathrm{SO}_{4}+60 \% \mathrm{~V}_{2} \mathrm{O}_{5}\right.$ and $\mathrm{Na}_{2} \mathrm{SO}_{4}+5 \% \mathrm{~V}_{2} \mathrm{O}_{5}$ $+5 \% \mathrm{NaCl}$ ) environments at $900^{\circ} \mathrm{C}$ after 10, 20, 35 and 50 cycles are shown in Figure 3 and Figure 4 . The ma-

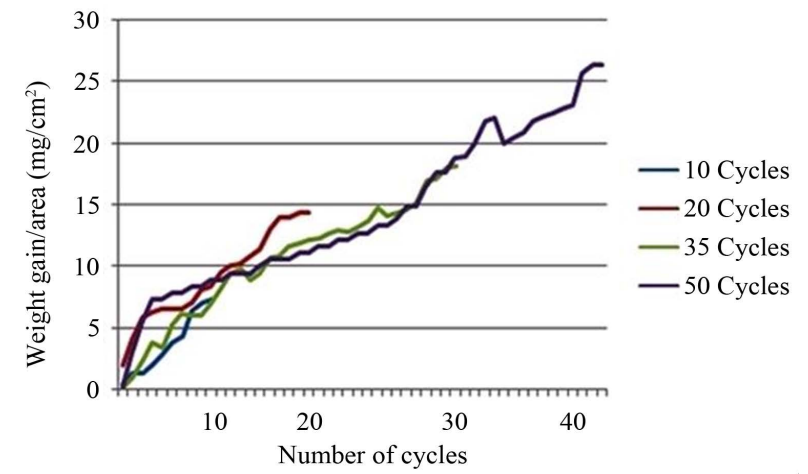

Figure 1. Weight gain/area vs. number of cycles plot for superfer $800 \mathrm{H}$ subjected to cyclic hot corrosion in $\mathrm{Na}_{2} \mathrm{SO}_{4}+60 \%$ $\mathrm{V}_{2} \mathrm{O}_{5}$ environment at $900^{\circ} \mathrm{C}$ for $10,20,35$ and 50 cycles. 


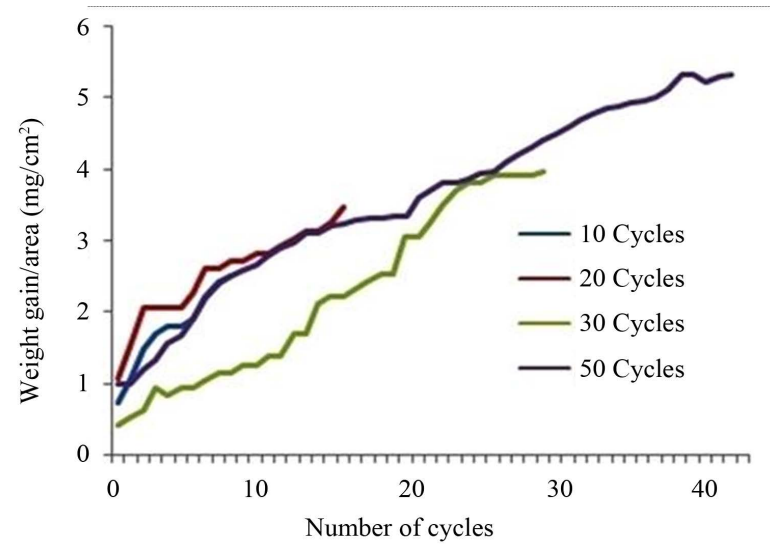

Figure 2. Weight gain/area vs. number of cycles plot for superfer $800 \mathrm{H}$ subjected to cyclic hot corrosion in $\mathrm{Na}_{2} \mathrm{SO}_{4}+5 \% \mathrm{~V}_{2} \mathrm{O}_{5}$ $+5 \% \mathrm{NaCl}$ environment at $900^{\circ} \mathrm{C}$ for $10,20,35$ and 50 cycles.

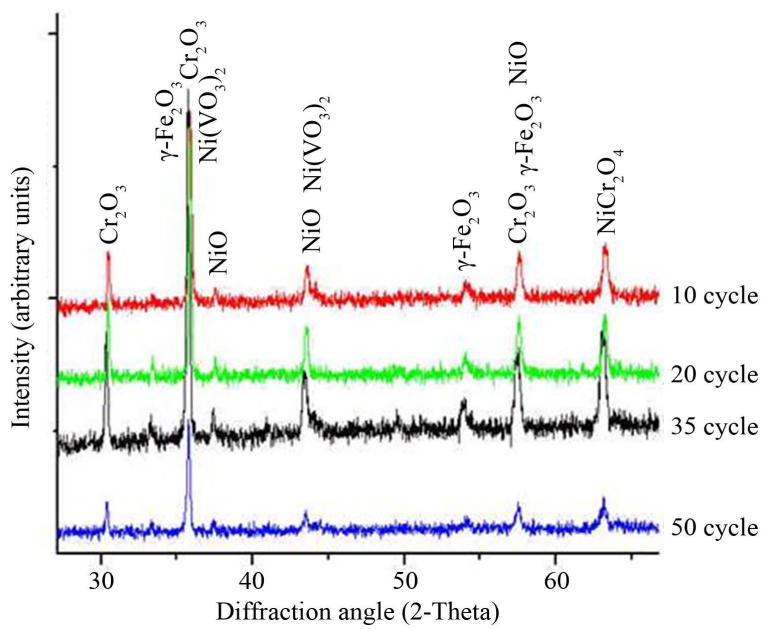

Figure 3. X-ray diffraction patterns for the super $800 \mathrm{H}$ subjected to cyclic hot corrosion in $\mathrm{Na}_{2} \mathrm{SO}_{4}+60 \% \mathrm{~V}_{2} \mathrm{O}_{5}$ environment at $900^{\circ} \mathrm{C}$ for $10,20,35$ and 50 cycles.

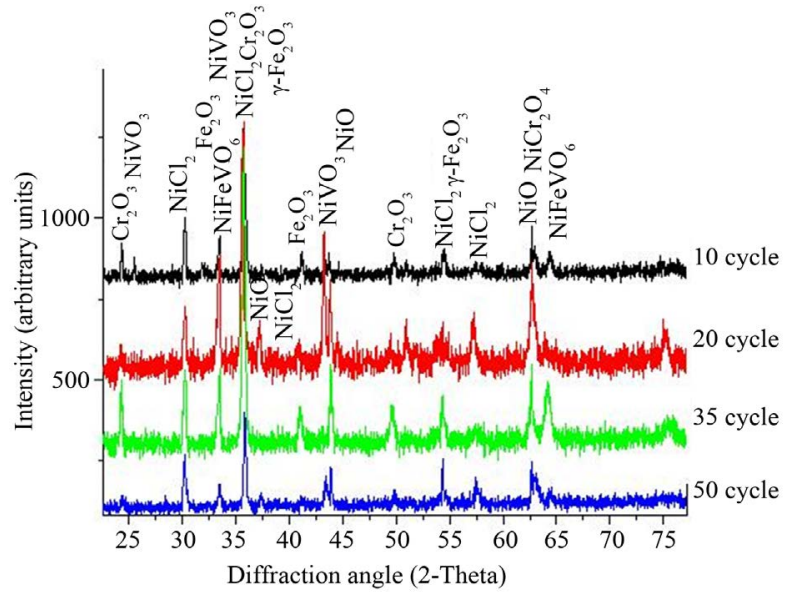

Figure 4. X-ray diffraction patterns for the super $800 \mathrm{H}$ subjected to cyclic hot corrosion in $\mathrm{Na}_{2} \mathrm{SO}_{4}+5 \% \mathrm{~V}_{2} \mathrm{O}_{5}+5 \% \mathrm{NaCl}$ environment at $900^{\circ} \mathrm{C}$ for $10,20,35$ and 50 cycles. 
Table 2. Variation of parabolic rate constant, kp with number of cycles.

\begin{tabular}{ccc}
\hline Number of Cycles & $\mathrm{Kp}\left(10^{-9} \mathrm{~g}^{2} \cdot \mathrm{cm}^{-4} \cdot \mathrm{s}^{-2}\right)\left(\mathrm{Na}_{2} \mathrm{SO}_{4}+60 \% \mathrm{~V}_{2} \mathrm{O}_{5}\right)$ & $\mathrm{Kp}\left(10^{-10} \mathrm{~g}^{2} \cdot \mathrm{cm}^{-4} \cdot \mathrm{s}^{-2}\right)\left(\mathrm{Na}_{2} \mathrm{SO}_{4}+5 \% \mathrm{~V}_{2} \mathrm{O}_{5}+5 \% \mathrm{NaCl}\right)$ \\
\hline 10 & 1.684 & 9.44 \\
20 & 2.931 & 1.986 \\
35 & 2.437 & 4.580 \\
50 & 3.119 & 4.767 \\
\hline
\end{tabular}

jor phases identified in $\mathrm{Na}_{2} \mathrm{SO}_{4}+60 \% \mathrm{~V}_{2} \mathrm{O}_{5}$ environments are $\mathrm{NiO}, \mathrm{Cr}_{2} \mathrm{O}_{3}, \mathrm{Ni}\left(\mathrm{VO}_{3}\right)_{2}, \mathrm{NiCr}_{2} \mathrm{O}_{4}$ and $\gamma-\mathrm{Fe}_{2} \mathrm{O}_{3}$. $\mathrm{NiCl}_{2}$ is the addition phase identified in the presence of $\mathrm{NaCl}$ salt.

\subsection{FE-SEM/EDAX Analysis of the Scale}

\subsubsection{Surface Morphology of the Scale}

FE-SEM/EDAX micrographs with EDS spectrum of the superfer $800 \mathrm{H}$ specimens after cyclic hot corrosion in molten salt $\left(\mathrm{Na}_{2} \mathrm{SO}_{4}+60 \% \mathrm{~V}_{2} \mathrm{O}_{5}\right.$ and $\left.\mathrm{Na}_{2} \mathrm{SO}_{4}+5 \% \mathrm{~V}_{2} \mathrm{O}_{5}+5 \% \mathrm{NaCl}\right)$ environments for 10, 20, 35, 50 cycles at $900^{\circ} \mathrm{C}$ are shown in Figure 5 and Figure 6, respectively. In superfer $800 \mathrm{H}$, the formation of hemispherical shaped protrusion was observed, which mainly consists of $\mathrm{NiO}, \mathrm{Cr}_{2} \mathrm{O}_{3}$ and $\mathrm{Fe}_{2} \mathrm{O}_{3}$ as the predominant phases.

\subsubsection{X-Ray Mapping}

The hot corroded samples were cut across the cross-section and mounted in transoptic mounting resin, mirrorpolished and gold coated to facilitate X-ray mapping by FE-SEM/EDAX of the different elements present across the scale. X-ray mapping analyses of the scale formed after hot corrosion in $\left(\mathrm{Na}_{2} \mathrm{SO}_{4}+60 \% \mathrm{~V}_{2} \mathrm{O}_{5}\right.$ and $\mathrm{Na}_{2} \mathrm{SO}_{4}+$ $5 \% \mathrm{~V}_{2} \mathrm{O}_{5}+5 \% \mathrm{NaCl}$ ) environments at $900^{\circ} \mathrm{C}$ for 10, 20, 35 and 50 cycles (Figure 7, Figure 8) reveals that the surface scale mainly consist of $\mathrm{Cr}, \mathrm{Ni}$ and $\mathrm{Fe}$ in the upper most part of the scale, presence of oxygen in the top scale shows the formation of $\mathrm{Cr}_{2} \mathrm{O}_{3}, \mathrm{NiO}$ and $\mathrm{Fe}_{2} \mathrm{O}_{3}$ layer. In the subscale region, there is a thick band of chromium (Cr) which indicates the formation of relatively dense scale of $\mathrm{Cr}_{2} \mathrm{O}_{3}$, meager amount of $\mathrm{S}$ is penetrated deep in to the substrate.

\section{Discussion}

The weight change data for superfer $800 \mathrm{H}$ subjected to hot corrosion test in molten salt environments are plotted in Figure 1 and Figure 2. It indicates that the superfer $800 \mathrm{H}$ followed a parabolic rate law up for both the environment. The higher weight gain of the specimens during the first few cycles might be due to the rapid formation of oxides (formation of $\mathrm{Cr}_{2} \mathrm{O}_{3}$ ) at the boundaries and within the open pores due to the penetration of the oxidizing species. Further subsequent increase in weight is gradual. Values of parabolic rate constant $\mathrm{Kp}\left(10^{-10}\right.$ $\mathrm{g}^{2} \cdot \mathrm{cm}^{-4} \cdot \mathrm{s}^{-1}$ ) were obtained from slope of the linear regression fitted line and are tabulated in Table 2. XRDanalysis of hot corroded samples indicates the formation of $\mathrm{Fe}_{2} \mathrm{O}_{3}, \mathrm{NiO}, \mathrm{Cr}_{2} \mathrm{O}_{3}$ and spinel $\left(\mathrm{NiCr}_{2} \mathrm{O}_{4}\right)$ as major phases. Surface morphology and composition analysis of corroded sample are shown in (Figure 5 and Figure 6). The EDAX analysis of the surface scale developed on superfer $800 \mathrm{H}$ in $\mathrm{Na}_{2} \mathrm{SO}_{4}+60 \% \mathrm{~V}_{2} \mathrm{O}_{5}$ environment (Figures 5(a)-(d)) is crack free with dense clusters mainly consisting of $\mathrm{Cr}, \mathrm{Fe}, \mathrm{Ni}$ and $\mathrm{O}$ rich elements, thereby suggesting the formation of $\mathrm{Cr}_{2} \mathrm{O}_{3}, \mathrm{Fe}_{2} \mathrm{O}_{3}$, $\mathrm{NiO}$ and their spinel $\left(\mathrm{NiCr}_{3} \mathrm{O}_{4}\right)$. Whereas scale developed on superfer $800 \mathrm{H}$ in $\mathrm{Na}_{2} \mathrm{SO}_{4}+5 \% \mathrm{~V}_{2} \mathrm{O}_{5}+5 \% \mathrm{NaCl}$ environment (Figures 6(a)-(d)) mainly consisting of $\mathrm{Cr}$, Fe, and $\mathrm{O}$ rich elements which suggesting the formation of $\mathrm{Cr}_{2} \mathrm{O}_{3}$ and $\mathrm{Fe}_{2} \mathrm{O}_{3}$. The formation of spinel of $\mathrm{NiCr}_{2} \mathrm{O}_{4}$ via solid phase reaction between $\mathrm{NiO}$ and $\mathrm{Cr}_{2} \mathrm{O}_{3}$ in the oxide scales helps to develop oxidation resistance as the spinel phase that usually has lower diffusion coefficients of the cations and anions than those in their parent oxides. The superfer 800H (Figure 5(d) and Figure 6(d)) show the formation of uneven protrusion in entire oxidised surface along the scale grain boundaries, similar protrusion behaviour was reported in the earlier literature [14] [15] during isothermal oxidation studies on plasma-sprayed NiCrAlY bond coat and oxidation and hot corrosion behaviours of superalloys at $900^{\circ} \mathrm{C}$.

$\mathrm{X}$-ray mapping (Figure 7) suggests that in molten salt environments, hot corrosion proceed through initiation and propagation of cracks, diffusion of molten salts through cracks and dissolution and re-precipitation of $\mathrm{Cr}_{2} \mathrm{O}_{3}$ 


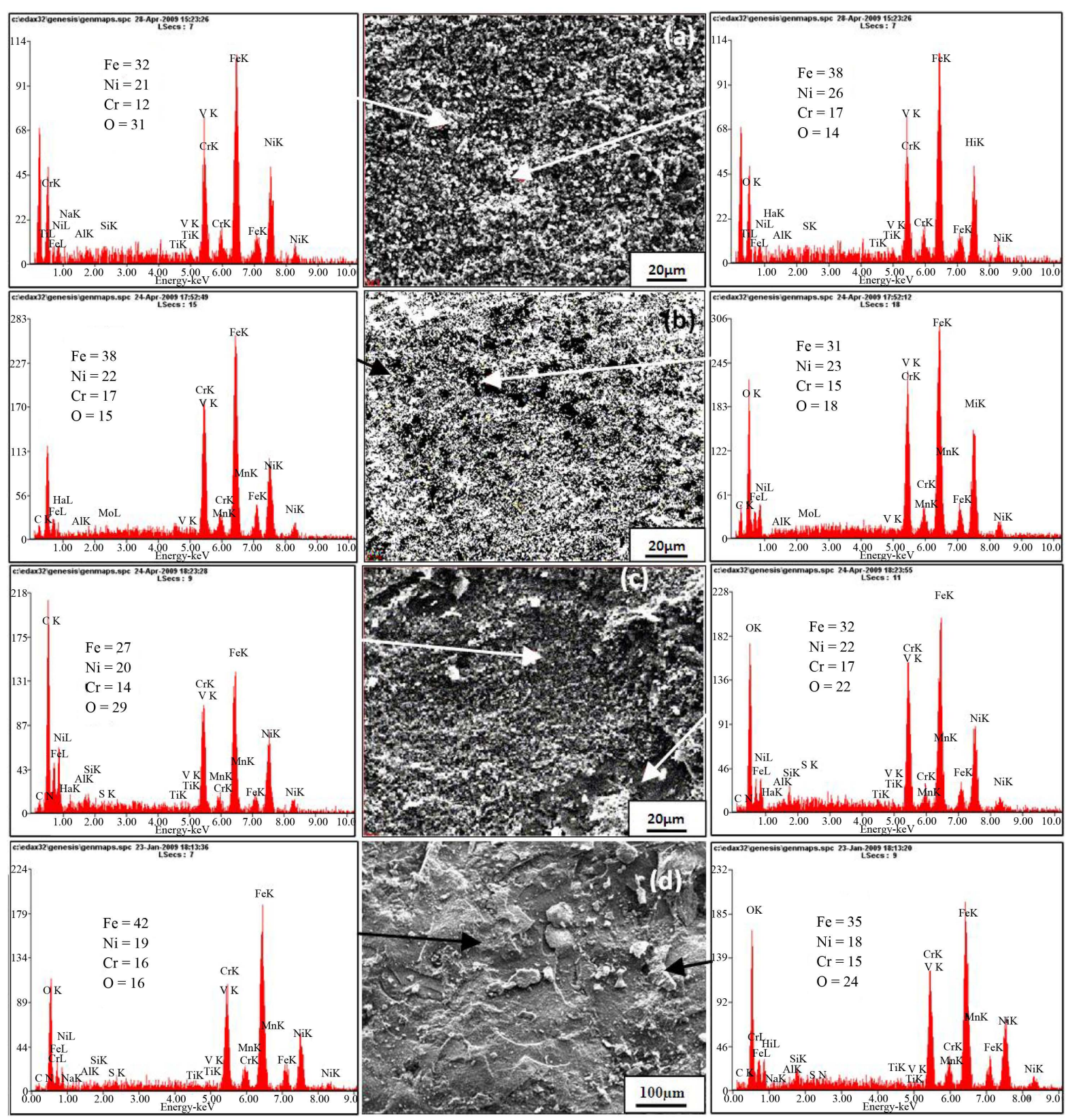

Figure 5. Oxide Scale morphology and variation of elemental composition across the cross-section of superfer $800 \mathrm{H}$ subjected to cyclic hot corrosion in $\mathrm{Na}_{2} \mathrm{SO}_{4}+60 \% \mathrm{~V}_{2} \mathrm{O}_{5}$ at $900^{\circ} \mathrm{C}$ after (a) 10 cycles, (b) 20 cycles (c) 35 cycles and (d) 50 cycles.

layer along the path of crack. In $\mathrm{Na}_{2} \mathrm{SO}_{4}+60 \% \mathrm{~V}_{2} \mathrm{O}_{5}$ salt after 20 cycles, cracks are clearly revealed (Figure 7(b)). It is also observed that crack initiated at the surface (scale) first propagates perpendicular to the surface and as it encounters any obstacle (inclusions, inter-metallic) it starts propagating parallel to the surface. Figure 7(c) shows crack propagation and salt penetration through cracks into the substrate. After 50 cycles (Figure $7(d)$ ), there is complete rupture of scale. In case of $\mathrm{Na}_{2} \mathrm{SO}_{4}+5 \% \mathrm{~V}_{2} \mathrm{O}_{5}+5 \% \mathrm{NaCl}$ environment, presence of $\mathrm{Cl}^{-}$ enhances the crack formation. Addition of $\mathrm{NaCl}$ accelerates the hot corrosion, as it reacts with the oxides thus releasing chlorine which in turn reacts with the oxides to form the volatile chlorides, as per the following reactions [16] [17].

$$
8 \mathrm{NaCl}(\mathrm{l})+2 \mathrm{Cr}_{2} \mathrm{O}_{3}(\mathrm{~s})+5 \mathrm{O}_{2}(\mathrm{~g})=4 \mathrm{Na}_{2} \mathrm{CrO}_{4}(\mathrm{~s})+4 \mathrm{Cl}_{2}(\mathrm{~g})
$$



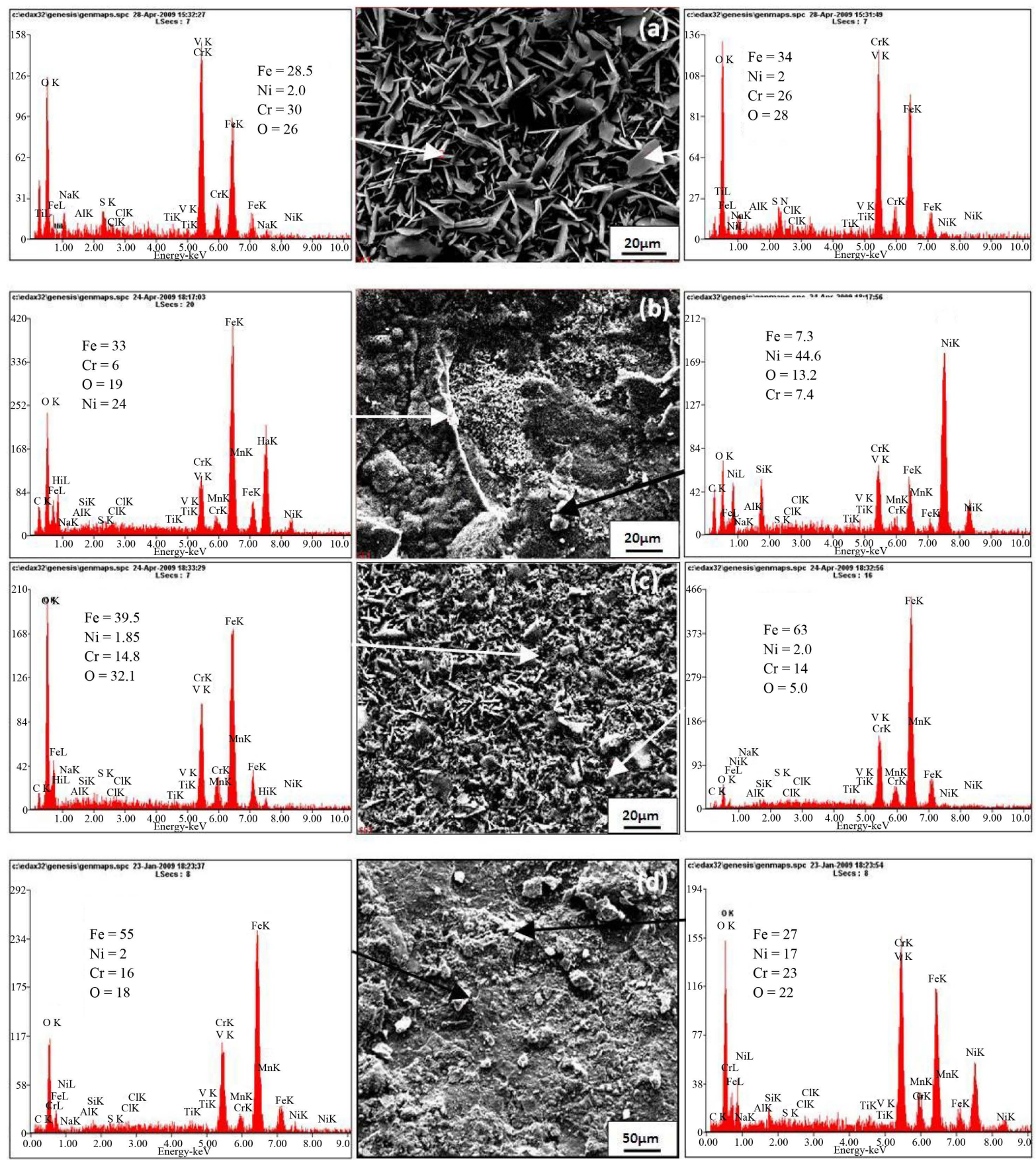

Figure 6. Oxide Scale morphology and variation of elemental composition across the cross-section of superfer $800 \mathrm{H}$ subjected to cyclic hot corrosion in $\mathrm{Na}_{2} \mathrm{SO}_{4}+5 \% \mathrm{~V}_{2} \mathrm{O}_{5}+5 \% \mathrm{NaCl}$ at $900^{\circ} \mathrm{C}$ after (a) 10 cycles, (b) 20 cycles (c) 35 cycles and (d) 50 cycles.

$\mathrm{Cl}_{2}$ is able to penetrate through oxide scales quickly along cracks and react with substrate elements such as Cr. Then volatile chlorides are formed:

$$
\mathrm{Cr}(\mathrm{s})+3 / 2 \mathrm{Cl}_{2}(\mathrm{~g})=\mathrm{CrCl}_{3}(\mathrm{~g})
$$

The volatile chlorides thus formed tend to diffuse out through the grain boundaries to the surface, and in doing so numerous pits and voids are generated at the grain boundaries, which can be seen clearly in Figure 8 . The chlorides may reoxidize on the surface of the scales: 

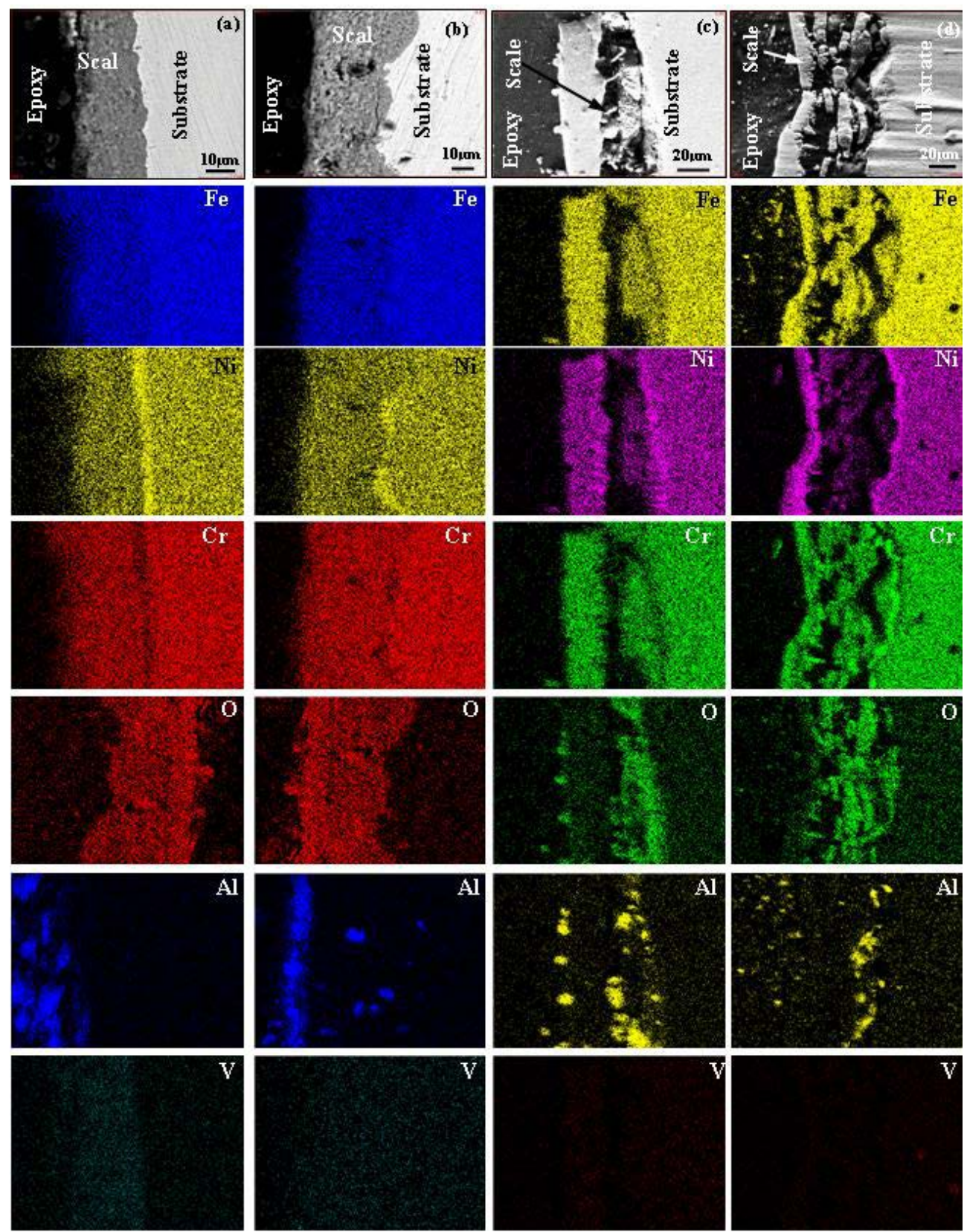

Figure 7. FE-SEM/EDAX analysis along with EDS spectrum for the superfer $800 \mathrm{H}$ subjected to cyclic hot corrosion in $\mathrm{Na}_{2} \mathrm{SO}_{4}+60 \% \mathrm{~V}_{2} \mathrm{O}_{5}$ at $900^{\circ} \mathrm{C}$ after (a) 10 cycles, (b) 20 cycles (c) 35 cycles and (d) 50 cycles.

$$
2 \mathrm{CrCl}_{3}(\mathrm{~g})+3 / 2 \mathrm{O}_{2}(\mathrm{~g})=\mathrm{Cr}_{2} \mathrm{O}_{3}(\mathrm{~s})+3 \mathrm{Cl}_{2}(\mathrm{~g})
$$

$\mathrm{Cl}_{2}$ is then regenerated and the corrosion repeated. Other alloy elements, such as $\mathrm{Ni}$, Ti etc. also follow the above reactions. The pits and voids, produced due to the formation of volatile chlorides, provide paths for the further penetration of corrosive species resulting in internal oxidation and sulphidation of the substrates as being reported by sidhu et al. [18].

It may be noticed that after 10 cycles in $\mathrm{Na}_{2} \mathrm{SO}_{4}+5 \% \mathrm{~V}_{2} \mathrm{O}_{5}+5 \% \mathrm{NaCl}$ environment (Figure 8(a)), there is no any distinct scale substrate interface, but initiation of crack propagation has been started in the scale and crack propagation path is clearly visible. Through these cracks, molten salt diffuses and attacks the substrate 

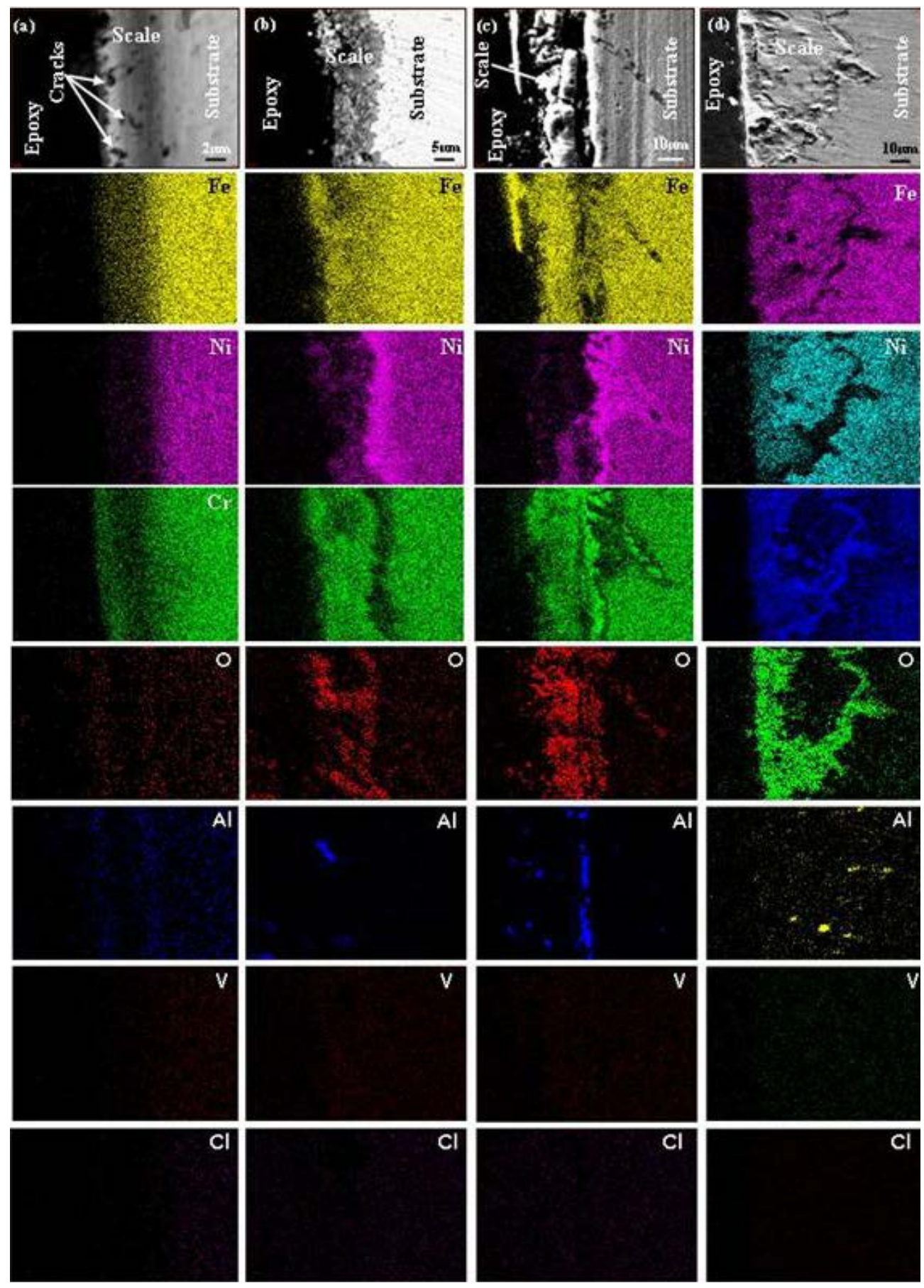

Figure 8. FE-SEM/EDAX analysis along with EDS spectrum for the superfer $800 \mathrm{H}$ subjected to cyclic hot corrosion in $\mathrm{Na}_{2} \mathrm{SO}_{4}+5 \% \mathrm{~V}_{2} \mathrm{O}_{5}+5 \% \mathrm{NaCl}$ at $900^{\circ} \mathrm{C}$ after (a) 10 cycles, (b) 20 cycles (c) 35 cycles and (d) 50 cycles.

material by dissolving the $\mathrm{Cr}_{2} \mathrm{O}_{3}$ layer (Figure 8(c)). Propagation of crack into the material, diffusion of molten salt through the cracks and dissolution and reprecipitation of $\mathrm{Cr}_{2} \mathrm{O}_{3}$ along the crack path is clearly visible in Figure 8(c). Figure 8(d) further supports the hot corrosion mechanism via crack propagation. Intensive spalling/ sputtering of the scale of the superfer $800 \mathrm{H}$ superalloy can be attributed to severe strain developed due to the precipitation of $\mathrm{Fe}_{2} \mathrm{O}_{3}$ from the liquid phase and interdiffusion of intermediate layers of iron oxide as has been reported by Sachs [19]. Further, the presence of different phases in a thin layer might impose severe strain on the 
film, which may result in cracking and peeling of the scale. Thermal cycles might have also produced cracks in the scale due to different values of thermal expansion coefficients of the substrate and the oxides formed in the scale. These cracks may have allowed the aggressive molten liquid phase to reach the metal substrate and causes internal oxidation. X-ray mapping of corroded superfer $800 \mathrm{H}$ also supports internal oxidation via cracks as there is higher percentage of $\mathrm{Cr}$ along with Oxygen along the path of crack.

\section{Conclusions}

- The formation of protective oxide scales such as $\mathrm{NiO}, \mathrm{Cr}_{2} \mathrm{O}_{3}$ and $\mathrm{NiCr}_{2} \mathrm{O}_{4}$ provide resistance to hot corrosion.

- Depletion of chromium occurs at scale metal interface, scale initially comprises of $\mathrm{Cr}_{2} \mathrm{O}_{3}$.

- During initial cycles Nickel concentration is high at metal interface region, as the number of cycles increase Nickel concentration increase in scale, scale has $\mathrm{NiO}$ and $\mathrm{Cr}_{2} \mathrm{O}_{3}$.

- Initial scale formed in $\mathrm{Na}_{2} \mathrm{SO}_{4}+60 \% \mathrm{~V}_{2} \mathrm{O}_{5}$ environment is adherent to substrate, while in case of chloride environments $\left(\mathrm{Na}_{2} \mathrm{SO}_{4}+10 \% \mathrm{NaCl}, \mathrm{Na}_{2} \mathrm{SO}_{4}+5 \% \mathrm{NaCl}+5 \% \mathrm{~V}_{2} \mathrm{O}_{5}\right)$ the initial scale formed is less adherent to substrate and crack propagation path is visible in initial cycles.

- Crack propagates via formation of $\mathrm{Cr}_{2} \mathrm{O}_{3}$. Region of crack propagation show Chromium and Oxygen in relatively large quantity.

\section{Acknowledgements}

The authors are very much thankful to Mr. K. Ramesh, General Manager (Commercial), and Mr. I. S. N Murthy, Mishra Dhatu Nigam Limited, Hyderabad (India), for providing the superalloys.

\section{References}

[1] Zhang, J.S., Hu, Z.Q., Murata, Y., Morinaga, M. and Yukawa, N. (1993) Design and Development of Hot CorrosionResistant Nickel-Base Single-Crystal Superalloys by the d-Electrons Alloy Design Theory: Part I. Characterization of the Phase Stability. Metallurgical Transactions A, 24, 2443-2450.

[2] Li, J. and Wahi, R.P. (1995) Investigation of Lattice Mismatch in the Polycrystalline Nickel-Base Superalloy IN738LC: Influence of Heat Treatment and Creep Deformation. Acta Metallurgica et Materialia, 43-2, 507-517.

[3] Wang, Y., Mukherji, D., Chen, W., Kuttner, T., Wahi, R.P. and Wever, H. (1995) The Cyclic Creep Behavior of NickelBase Superalloy IN738LC. 86, 365-370.

[4] Chen, H., Chen, W., Mukherji, D., Wahi, R.P. and Wever, H. Z. (1995) Cyclic Life of Superalloy IN738LC under InPhase and Out-of-Phase Thermo-Mechanical Fatigue Loading. Z. Metalkd, 86-6, 423-427.

[5] Maledi, N.B., Potgieter, J.H., Sephton, M., Cornish, L.A., Chown, L. and Suss, R. (2006) International Platinum Conference "Platinum Surges Ahead". The Southern African Institute of Mining and Metallurgy, Sun City, 81-90.

[6] Bettge, D., Osterle, W. and Ziebs, J.Z. (1995) Temperature Dependence of Yield Strength and Elongation of the Nickel-Base Superalloy IN738LC and the Corresponding Microstructural Evolution. Z. Metalkd, 86-3, 190-197.

[7] Esmaeili, S., Engler-Pinto Jr., C.C., Ilschner, B. and Rezai-Aria, F. (1995) Interaction between Oxidation and ThermoMechanical Fatigue in IN738LC Superalloy. Scripta Metallurgica et Materiallia, 33, 1777-1781.

[8] Rocca, E., Steinmetz, P. and Moliere, M. (2003) Revisiting the Inhibition of Vanadium-Induced Hot Corrosion in Gas Turbines. Journal of Engineering for Gas Turbines and Power, 125, 1-9. http://dx.doi.org/10.1115/1.1456095

[9] Deb, D., Iyer, S.R. and Radhakrishnan, V.M. (1996) A Comparative Study of Oxidation and Hot Corrosion of a Cast Nickel Base Superalloy in Different Corrosive Environments. Materials Letters, 29, 19-23. http://dx.doi.org/10.1016/S0167-577X(96)00109-7

[10] Stringer, J. (1977) Hot Corrosion of High-Temperature Alloys. Annual Review of Materials Science, 7, 477-509. http://dx.doi.org/10.1146/annurev.ms.07.080177.002401

[11] Hejwowski, T. (2006) Investigations of Corrosion Resistance of Fe-, Ni- and Co-Based Hardfacings. Vacuum, 80, 1386-1390. http://dx.doi.org/10.1016/j.vacuum.2006.01.021

[12] Otero, E., Pardo, A., Hernaez, J. and Perez, F.J. (1992) The Corrosion of Some Superalloys (at $1000 \mathrm{~K}$ ) in Molten Eutectic Mixture $60 \% \mathrm{~V}_{2} \mathrm{O}_{5}-40 \% \mathrm{Na}_{2} \mathrm{SO}_{4}$. The Influence of the Oxygen and Carbon Residues. Corrosion Science, 34, 1747-1757. http://dx.doi.org/10.1016/0010-938X(92)90006-O

[13] Gurrappa, I. (1999) Hot Corrosion Behavior of CM 247 LC Alloy in $\mathrm{Na}_{2} \mathrm{SO}_{4}$ and $\mathrm{NaCl}$ Environments. Oxidation of Metals, 51, 353-382. http://dx.doi.org/10.1023/A:1018831025272 
[14] Choi, H., Yoon, B., Kim, H. and Lee, C. (2002) Isothermal Oxidation of Air Plasma Spray NiCrAlY Bond Coatings. Surface and Coatings Technology, 150, 297-308. http://dx.doi.org/10.1016/S0257-8972(01)01557-2

[15] Kamal, S., Jayaganthan, R. and Prakash, S. (2010) Evaluation of High Temperature Cyclic Oxidation and Hot Corrosion Behaviors of Superalloys at $900^{\circ} \mathrm{C}$. Bulletin of Material Science, 33, 299-306.

[16] Mckee, D.W., Shore, D.A. and Luthra, K.L. (1978) The Effect of $\mathrm{SO}_{2}$ and $\mathrm{NaCl}$ on High Temperature Hot Corrosion. Journal of the Electrochemical Society, 3, 411-419. http://dx.doi.org/10.1149/1.2131463

[17] Shinata, Y. (1987) Accelerated Oxidation Rate of Chromium Induced by Sodium Chloride. Oxidation of Metals, 27, 315-322. http://dx.doi.org/10.1007/BF00659274

[18] Sidhu, T.S., Malik, A., Prakash, S. and Agrawa, R.D. (2006) Cyclic Oxidation Behavior of Ni- and Fe-Based Superalloys in Air and $\mathrm{Na}_{2} \mathrm{SO}_{4}-25 \% \mathrm{NaCl}$ Molten Salt Environment at $800^{\circ} \mathrm{C}$. International Journal of Physical Sciences, $\mathbf{1}$, 027-033.

[19] Sachs, K. (1958) Accelerated High Temperature Oxidation due to Vanadium Pentoxide. Metallurgia, 167-173. 
Scientific Research Publishing (SCIRP) is one of the largest Open Access journal publishers. It is currently publishing more than 200 open access, online, peer-reviewed journals covering a wide range of academic disciplines. SCIRP serves the worldwide academic communities and contributes to the progress and application of science with its publication.

Other selected journals from SCIRP are listed as below. Submit your manuscript to us via either submit@scirp.org or Online Submission Portal.
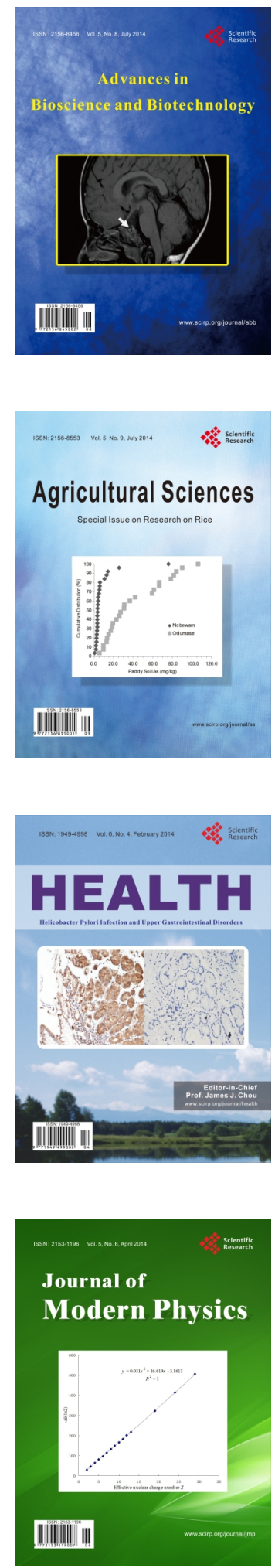
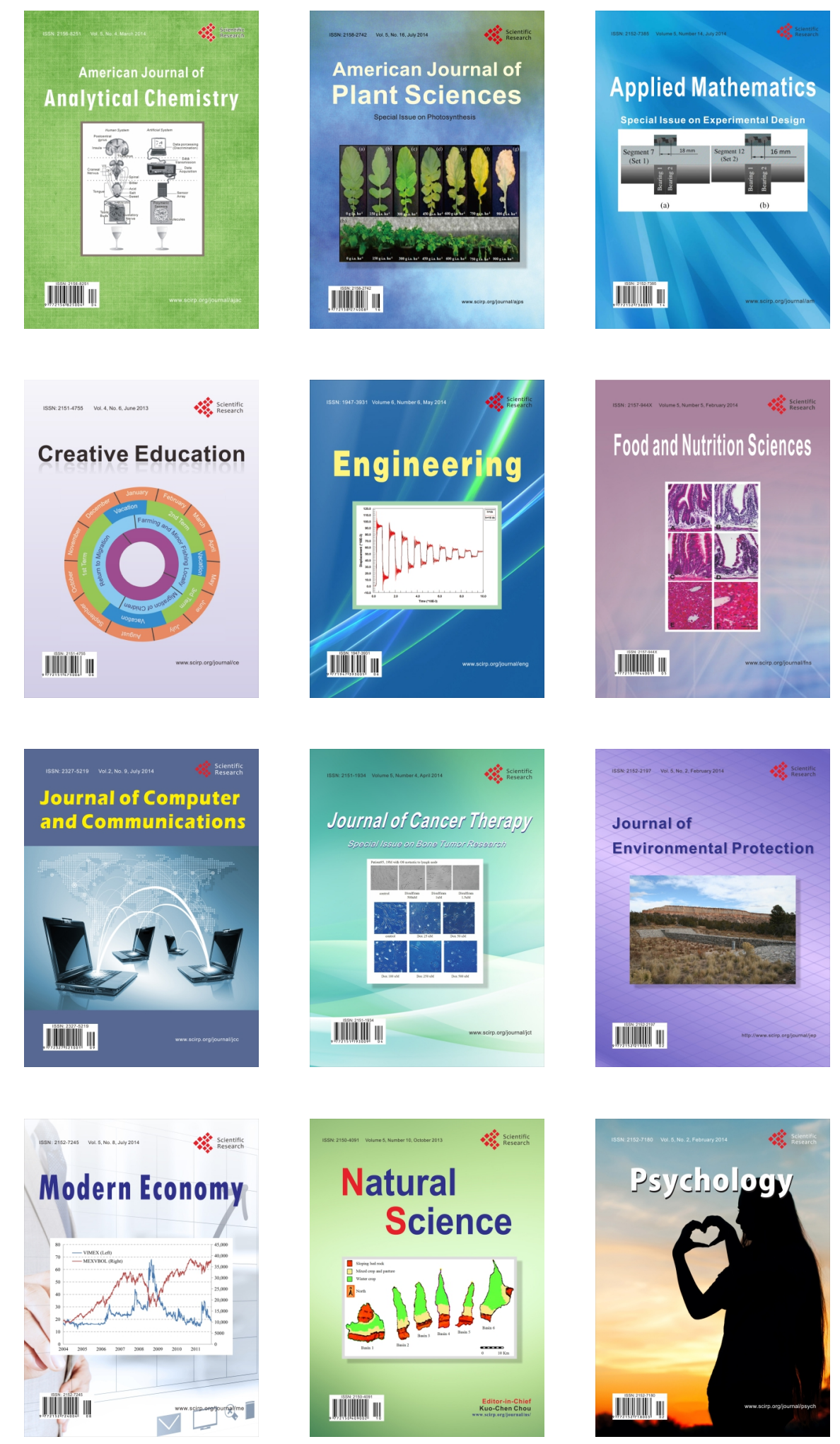